\title{
TOXICITY OF CHLOROPHYLLIN COMPOUND ON FIELD AND SUSCEPTIBLE STRAINS OF SPODOPTERA LITTORALIS, AND ITS BIOCHEMICAL IMPACT ON A, B AND ACETYLCHOLIN- ESTERASES
}

\author{
SAMEH M. ABD EL-NABY
}

Plant Protection Research Institute (PPRI), ARC, Dokki, Giza, Egypt

(Manuscript received 9 September 2018)

\begin{abstract}
$\mathrm{C}$ hlorophyllin ( $\mathrm{CHL}$ ) is water-soluble analogue of chlorophyll pigment everywhere. This is due to the presence of many useful properties and its use as food additives and in alternative medicine. The study field was investigational at station of the faculty of Agricultural, Cairo University, at Giza governorates, Egypt. Result indicated that sub-lethal concentrations of sodium copper chlorophyllin and magnesium copper chlorophyllin on field and susceptible strains Spodoptera littoralis. The concentration $\left(10^{-2} \mathrm{M}\right)$ for both sodium copper chlorophyllin and magnesium copper chlorophyllin was more effective than concentration $\left(10^{-3} \mathrm{M}\right)$ on field strains and susceptible strains of Spodoptera littoralis. The determination activity level a-esterases, $\beta$ esterases and acetylcholine were determined in the total body homogenates of Spodoptera littoralis. The results show that $\mathrm{CHL}$ was affected both $(a-\beta)$ esterase enzyme. $\beta$-esterase activity showed significant activity increase, and a-esterase showed significant activity reduction in most treatment. on the other hand the acetylcholinesterase activity show low various.

Key wards: Spodoptera littoralis, photoinsecticide, Photosensitizer, Copper chlorophyllin, Magnesium Chlorophyllin, Profenofos, Organophosphorous (OP), $a$ and $\beta$ esterase enzyme.
\end{abstract}

\section{INTRODUCTION}

Chlorophyll is extracted from the silkworm stools used as a medicine for stomach disorders such as hepatitis ulcers. It is also used to treat liver and blood diseases (Koulet al., 1994). Sodium chlorophyll and copper extracted from the activity of chlorophyll how's antibacterial and has medical applications. Used in the treatment of hepatitis, acute pancreatitis, chronic nephritis, gastric disorders and leukocyte deficiency (Majumder, 1997). Xanthene derivatives and other light-sensitive materials, after exposed to visible light producing superoxide anions and singlet oxygen and (Ben Amor and Jori, 2000). Photosensitization involves activation of light-sensitive compounds, producing chemical reactions that harm or destroy cells; in some cases the excited Photosensitizer was changed into a toxic photoproduct (Spikes, 1985).In many cases, the effect of the phototoxicity of the chemical compound is entirely developed only in the presence of oxygen; hence the photoinsecticide actions appear to be of the photodynamic style (Heitz, 1987). The light and many of dyes and related 
TOXICITY OF CHLOROPHYLLIN COMPOUND ON FIELD AND SUSCEPTIBLE STRAINS OF SPODOPTERA LITTORALIS, AND ITS BIOCHEMICAL IMPACT ON A, B AND ACETYLCHOLIN- ESTERASES

compounds can operate as photosensitizers; Photosensitization is a phenomenon happen in biological systems (Black, 1987).

The three broad categories of enzymes involved in the detoxification of pesticides are the mixed function oxidases (MFO), esterases and glutathione Stransferases (WHO 1981, 1998). The major mechanism of Insecticide resistant to organophosphate in Cx. quinquefasciatus Say is through highly inactive non-specific esterase isoenzymes, which seem to metabolize pesticides to harmless products (Villani et al., 1983).

The basic methods for insecticide resistance in all insects are changes in the insecticide target site or changes in the rate at which the insecticide is detoxified. So far esterases, are known to be involved in the detoxification of the major groups of insecticides (Herron, et al., 2004; Pethuan, et al., 2007). insecticide contain carboxylester and phosphotriester bonds, can be attack by esterase enzymes (Brattsten, 1992).The nerve synapses of insects contain a chemical mediator known as acetylcholine (AchE), through which nerve impulses transmitted from one nerve axon to another. Acetylcholinesterases hydrolyze acetylcholine to prevent its accumulation at the nerve synapses since its accumulation leading to death due to the disruption of nerve transmission. Acetylcholinesterase responsable to transport of cholinesterase in the nervous system and is the target site of inhibition by organophosphorus and carbamate insecticides (El-Defrawi, et al., 1964). The changes in ChE activity of $S$, littoralis larvae during thecourse of poisoning with IGR's/insecticides mixtures was studied (Abdel Hafez et al., 1993). All tested compounds caused variable reduction in the activity of acetylcholinesterase than in control. The highest level of reduction was obtained for the IGR diflubenzuron alone or in its mixtures. Data obtained from field experiments were the same as those on laboratory experiments. The non-specific esterases ( $\alpha$ - and $\beta$-esterases), which are considered as aromatic ester hydrolases. Evaluated the esterases hydrolyzing $\alpha$ naphthyl acetate and $\beta$-naphthyl acetate in larvae of $S$. littoralis was evaluated colourimetrically in two susceptible and four resistant strains (Riskallah, et al., 1979). Their results indicated that fenitrothion resistant strain showed activity of esterases 24 times greater than the S-strain.

\section{Aim of the work}

The present study was to investigate the Toxicity of chlorophyllin compound on field and susceptible of strains Spodoptera littoralis, and its biochemical impact on a, $\beta$ and acetylcholin- esterases 


\section{MATERIALS AND METHODS}

\section{Expeimental field}

The study field was investigational at station of the faculty of Agricultural, Cairo University, Giza, Egypt during the summer season 2015/2016.

\section{Toxicty expeimental design}

The experimental area of about 0.5 feddan was divided into 61plots,each plots equal $\left(20 \mathrm{~m}^{2}\right)$. Each plot consisted of 3 rows, 6 meter long and onemeter wide. Tomato seedlings were planted on rows separated by $90 \mathrm{~cm}$ distance. One-month-old tomato seedlings were planted. All experimental plots received regular agricultural practices except insecticide application. The treatments were performed two-monthday post planting of tomato seedlings and they were distributed as follows:

- Three experimental plots were sprayed with Photosensitizer (Copper chlorophyllin Cu $10^{-2} \mathrm{M}$ ).

- Three experimental plots were sprayed with Photosensitizer (Copper chlorophyllin Cu $10^{-3} \mathrm{M}$ ).

- Threeexperimental plots were sprayed with Photosensitizer ( Magnesium Chlorophyllin $\mathrm{Mg} 10^{-2} \mathrm{M}$ ).

- Three experimental plots were sprayed with Photosensitizer (Magnesium Chlorophyllin $\mathrm{Mg} 10^{-3} \mathrm{M}$ ).

- Three experimental plots were sprayed with insecticide (Profenofos72\% E.C) using recommended rate by the manufacturer $(1 \mathrm{~cm} /$ liter $)$.

- Three experimental plots were sprayed with water as a control group.

Plant samples were taken before spraying and after spraying on $1^{\text {st }}, 3^{\text {rd }}, 7^{\text {th }}, 10^{\text {th }}$ and 15 day. The sample included 20 plants which were randomly selected from each plot and investigated for alive insects. The third leave of each seedling was carfully investigated, observations and recorded the number of cotton leaf worm Spodoptera littoralis larvae. The reduction in the number was calculated by using Henderson and Tillton equation(Henderson and Tilton, 1955).

\section{Data analysis}

Data were analyzed by completely randomized ANOVA, and compared by Duncan's multiple range test at $\mathrm{P}<0.05$.

\section{Biochemical study:}

\section{Insects:}

A laboratory strain of the cotton leafworm Spodoptera littoralis was obtained from the Central Agricultural Pesticide Laboratory that established under constant conditions of $25^{\circ} \mathrm{C} \pm 1$ and $70 \pm 5 \%$ R.H. and out of any contamination with chemicals till the time of study. The strain was reared in the laboratory as described 
by El-Defrawi et al., (1964) under the previous optimum condition during the experiment. Serial concentration of Copper chlorophyllin and different concentration of Magnesium chlorophyllin, a Castor-bean leaves were dipped for 60 seconds in each aqueous concentration of the tested compound then left for one hour to dry. Newly

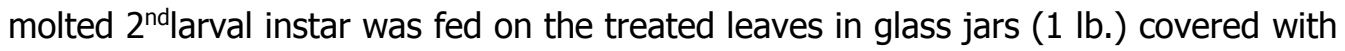
muslin for 24 hrs. After feeding, the treated larvae were transferred onto untreated leaves and exposed to sunlight. three replicates (each one had 20 larvae).

\section{Direct Sunlight :}

The treated larvae were exposed to the sunlight for 30 min., 60 and $120 \mathrm{~min}$. The fluency rate measured by the dosimeter taken as the average of intensities during exposure time.

\section{Dark experiment :}

The larvae treated with Copper chlorophyllin, MagnesiumChlorophyllinleft in the dark until the end of larval life.

\section{Enzyme assays :}

The activity enzyme (alpha Esterases, beta esterase and acetylcholineesterase) were determined in the total body homogenates for enzyme assays after exposure for different interval to sunlight.

\section{-Determination of acetylcholine esterase (AChE) activity:}

* Transaminases were determined according to Simpson et al. (1964) using acetylcholine bromide ( $\mathrm{AChBr}$ ) as substrate.

\section{Determination of non-specific esterases activities :}

$\alpha$ and $\beta$ esterases were determined according to Van Asperen (1962) using $\alpha$ - and $\beta$ naphthyl acetate as substrates respectively.

\section{RESULTS AND DISCUSSION}

\section{Toxicological study:}

Table 1. Toxicity data and resistance ratios of Copper chlorophyllin and Magnesium Chlorophyllin against $2^{\text {nd }}$ instar larvae of $S$. littoralis susceptible strain.

\begin{tabular}{|c|l|c|c|c|c|c|c|c|}
\hline No & Line name & $\mathrm{LC}_{50}$ & $\mathrm{LC}_{90}$ & Index & RR & Slope & Lower limit & Upper limit \\
\hline 1 & Mg-Ch 2 hr & 0.0008 & 725.647 & 100 & 1 & 0.216 & $-\cdots$ & $-\cdots$ \\
\hline 2 & Mg-Ch 30min & 0.0023 & 17.45 & 34.783 & 2.875 & 0.33 & ---- & $-\cdots$ \\
\hline 3 & Mg-Ch1 hr & 0.0051 & $1.02 \mathrm{E}+05$ & 15.686 & 6.375 & 0.176 & $-\cdots$ & $-\cdots$ \\
\hline 4 & CU-Ch 2 hr & 0.013 & 21485.29 & 6.154 & 16.25 & 0.206 & $-\cdots$ & $-\cdots$ \\
\hline 5 & CU-Ch 1 hr & 0.063 & $2.20 \mathrm{E}+05$ & 1.27 & 78.75 & 0.196 & $-\cdots$ & $-\cdots$ \\
\hline 6 & CU-Ch 30min & 62021.64 & $4.39 \mathrm{E}+20$ & $1.29 \mathrm{E}-06$ & $7.75 \mathrm{E}+07$ & 0.081 & $-\cdots$ & $-\cdots$ \\
\hline
\end{tabular}

Index compared with Mg-Ch $2 \mathrm{hr} \quad$ Resistance Ratio (RR) compared with Mg-Ch $2 \mathrm{hr}$

$* \mathrm{Mg}-\mathrm{CH}$ 30min : (S littoralis treated by magnesium chlorophyllin, exposure for half hour of sunlight )

$* \mathrm{Mg}-\mathrm{CH} 1 \mathrm{~h} \quad$ : (S littoralistreated by magnesium chlorophyllin, exposure for one hour of sunlight )

$* \mathrm{Mg}-\mathrm{CH} 2 \mathrm{~h} \quad:$ (S littoralistreated by magnesium chlorophyllin, exposure for two hour of sunlight)

*CU-CH 30min: (S littoralis treated by Sodium copper chlorophyllin, exposure for half hour of sunlight )

$* \mathrm{CU}-\mathrm{CH} 1 \mathrm{~h} \quad:$ ( $S$ littoralistreated by Sodium copper chlorophyllin, exposure for one hour of sunlight )

$* \mathrm{CU}-\mathrm{CH} 2 \mathrm{~h} \quad:$ (S littoralistreated by Sodium copper chlorophyllin, exposure for two hour of sunlight ) 
Table (1) and fig. (1), indicated that the tested susceptible strain to the photosensitizer (magnesium chlorophyllin) exposure to sunlight for two hour was the most susceptible $\mathrm{LC}_{50}=0.0008 \mathrm{M}$ compared to the other treated and has resistance ratio $(R R=1)$, on the other hand, the treated $S$. littoralis after exposure to sunlight for 30 min. showed $\mathrm{LC}_{50}=0.0023 \mathrm{M}$ and resistance ratio $(\mathrm{RR}=2.875)$ and treated $S$. littoralis exposure to sunlight for one hour show $\mathrm{LC}_{50}=0.0051 \mathrm{M}$ and resistance ratio $(R R=6.375)$. From this information it could be conclude that there is a direct correlation with the exposure time, and concentration with mortality, where the increase of exposure time and concentration led to increase the proportion of death. the photosensitizer magnesium chlorophyllin more effective than copper chlorophyllin, where exposure to sunlight for two hour give $\mathrm{LC}_{50}=0.013 \mathrm{M}$ compared to the other treated and resistance ratio $(\mathrm{RR}=16.25)$.on the other hand, treated Spodoptera littoralis exposure to sunlight for one hour show $\mathrm{LC}_{50}=0.063 \mathrm{M}$ and resistance ratio $(\mathrm{RR}=78.75)$ and the treated Spodoptera littoralis exposure to sunlight for $30 \mathrm{~min}$. showed $L_{50}=62021.64 \mathrm{M}$ and resistance ratio $(R R=7.75 E+07)$. In this treatment by chlorophyllin under darkness, no significant mortality occurs. Photosensitization involving light, photosensitizer and oxygen is potentially damaging, Singlet oxygen one of the main responsible for caused harmful in biological systems (Weishaput, et al., 1976). UV/Visible light can penetrate in tissues about $1 \mathrm{~cm}$ depth, deepened on wavelength (Svaasand et al., 1990).

Fig. 1. Log-probit concentration lines of Copper chlorophyllin and Magnesium

Chlorophyllinon the $2^{\text {nd }}$ larval instar of $S$. littoralisof laboratory strains

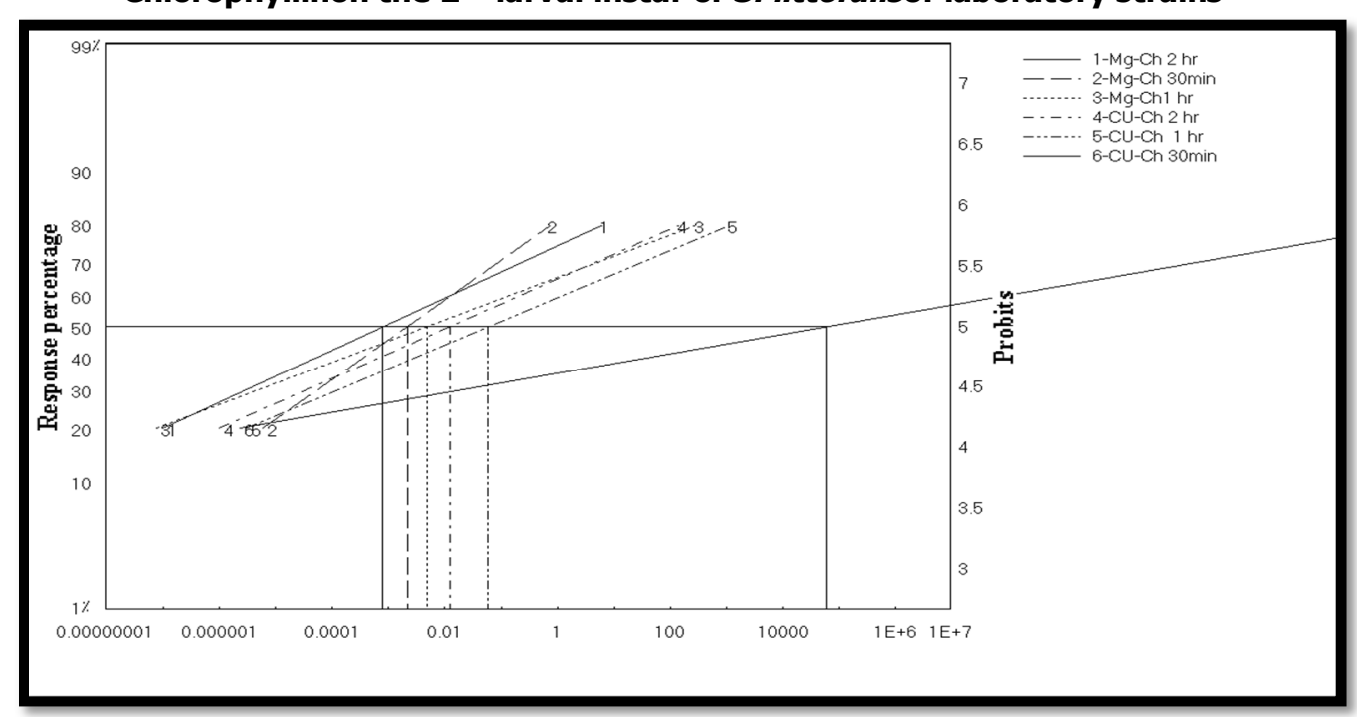

Field study

Two photosensitizers with two concentrations for each, were applied against $S$. littoralis in tomato field during summer at season 2015/2016. At the same time profenofos insecticide was sprayed with recommended dose and water was sprayed as a control group. 
The number live larvae of $S$. littoralis was counted on the $1^{\text {st }}, 7^{\text {th }}, 10^{\text {th }}$ and $15^{\text {th }}$ day in each treatment. Statistical analysis were conducted using one way ANOVA between all treatments through investigated days and also between days for each treatment. Reduction percentages were also calculated using means of a live larvae for each treatment in comparing with those alive in control group.

From table (2), the tested compound, Photosensitizer Magnesium Chlorophyllin $\left(10^{-2} \mathrm{M}\right.$ and $\left.10^{-3} \mathrm{M}\right)$, Photosensitizer Copper chlorophyllin, $\left(10^{-2} \mathrm{M}\right.$ and $\left.10^{-3} \mathrm{M}\right)$ and profenofos insecticide after one day sprayed showed high reduction against second instars $S$. littoralis( $74.60 \%, 61.83 \%, 56.31 \%, 46.33 \%$ and $55.24 \%$ ), respectively. After $7^{\text {th }}$ days sprayed the data showed that, All the tested compound, Photosensitizer Magnesium Chlorophyllin(10-2 $\mathrm{M}$ and $10^{-3}$ $\mathrm{M})$, Photosensitizer Copper Chlorophyllin $\left(10^{-2} \mathrm{M}\right.$ and $\left.10^{-3} \mathrm{M}\right)$ and profenofos insecticide after one day sprayed showed high reduction against second instars S. littoralis( $85.20 \%, 73.63 \%$, $75.99 \%, 70.56 \%$ and $73.88 \%$ ), respectively. After $10^{\text {th }}$ days sprayed the data showed that, All the tested compound, Photosensitizer Magnesium Chlorophyllin $\left(10^{-2} \mathrm{M}\right.$ and $\left.10^{-3} \mathrm{M}\right)$, Photosensitizer Copper Chlorophyllin $\left(10^{-2}\right.$ and $\left.10^{-3}\right)$ and profenofos insecticide after one day sprayed showed high

Reduction against second instars S. littoralis (88.54\%, 80.93\%, 80.53\%, $74.31 \%$ and $80.33 \%)$, respectively. After 15 days sprayed the data showed that, All the tested compound, Photosensitizer Magnesium Chlorophyllin $\left(10^{-2}\right.$ and $\left.10^{-3}\right)$, Photosensitizer Copper Chlorophyllin $\left(10^{-2}\right.$ and $\left.10^{-3}\right)$ and profenofos insecticide after one day sprayed showed high reduction against second instars Spodoptera littoralis( $86.59 \%, 72.05 \%, 74.32 \%, 71.34 \%$ and $83.53 \%)$, respectively.

These results showed that Magnesium Chlorophyllin $10^{-2} \mathrm{M}$ was more effective from first day against second instars Spodoptera littoralis. The results showed that, Means within a column by same letter are no significantly different by Duncan's Multiple Range Test. Small letters indicate to the significant differences between days while capital letters indicate to significant differences between treatments. IS= insignificant

The data showed gradual increase in the mortality with increase time interval after treatment. The level of mortality was also increased generally with concentration of the tested compounds. The same results were found by McNeill and Goldson (2001). The Current results show that the efficiency of photosensitizers as pesticides is influenced by a variety of factors.

Concentration of photosensitizers and exposure period. The rate of the photosensitized killing of insects appeared to rise with prolongation of post treatment exposure to light. 
Table 2. Efficiency of Magnesium Chlorophyllin, Copper chlorophyllin and Profenofos against cotton leaf worm (Spodoptera littoralis) larvae on Tomato field.

\begin{tabular}{|c|c|c|c|c|c|c|c|c|c|c|c|c|c|}
\hline \multirow{4}{*}{ Formulation } & \multirow{4}{*}{$\begin{array}{l}\text { Rate } \\
\mathrm{m} / \mathrm{L}\end{array}$} & \multicolumn{10}{|c|}{ Mean of alive larvae \pm SE and its reduction percentage } & \multirow{4}{*}{$\begin{array}{c}F \\
\text { value }\end{array}$} & \multirow{4}{*}{$\begin{array}{c}P \\
\text { value }\end{array}$} \\
\hline & & \multirow[t]{3}{*}{ Before spray } & \multicolumn{9}{|c|}{ Day post spray } & & \\
\hline & & & \multicolumn{2}{|c|}{1} & \multicolumn{2}{|c|}{7} & \multicolumn{3}{|c|}{10} & \multicolumn{2}{|c|}{15} & & \\
\hline & & & Meant SE & $\begin{array}{c}\text { Reduction } \\
(\%)\end{array}$ & Meant $\mathrm{SE}$ & $\begin{array}{c}\text { Reduction } \\
(\%)\end{array}$ & & Mean \pm SE & $\begin{array}{l}\text { Reductio } \\
n(\%)\end{array}$ & Mean \pm SE & $\begin{array}{c}\text { Reduction } \\
(\%)\end{array}$ & & \\
\hline \multirow{2}{*}{$\begin{array}{l}\text { MagnesiumChloroph } \\
\text { yllin }\end{array}$} & $10^{-2}$ & $9.73 \pm 0.55 \mathrm{Aa}$ & $2.30 \pm 0.15 B d$ & 74.60 & $1.27 \pm 0.11 \mathrm{CC}$ & 85.2 & 0.90 & $\pm \quad 0.11 C D C$ & 88.54 & $0.43 \pm 0.09 \mathrm{Cc}$ & 86.59 & 211.087 & 0.000 \\
\hline & $10^{-3}$ & $7.60 \pm 0.44 A b$ & $2.70 \pm 0.12 B d$ & 61.83 & $1.77 \pm 0.12 C \mathrm{C}$ & 73.63 & 1.17 & $\pm \quad 0.14 C D C$ & 80.93 & $0.70 \pm 0.13 \mathrm{Dbc}$ & 72.05 & 151.899 & 0.000 \\
\hline \multirow{2}{*}{$\begin{array}{c}\text { Copper } \\
\text { chlorophyllin }\end{array}$} & $10^{-2}$ & $9.10 \pm 0.67 \mathrm{Aa}$ & $3.70 \pm 0.20 B C$ & 56.31 & $1.93 \pm 0.14 \mathrm{CC}$ & 75.99 & 1.43 & $\pm \quad 0.18 \mathrm{CDbc}$ & 80.53 & $0.77 \pm 0.10 \mathrm{Dbc}$ & 74.32 & 101.970 & 0.000 \\
\hline & $10^{-3}$ & $10.27 \pm 0.56 \mathrm{Aa}$ & $5.13 \pm 0.21 \mathrm{Bb}$ & 46.33 & $2.67 \pm 0.25 \mathrm{Cb}$ & 70.56 & 2.13 & $\pm \quad 0.29 \mathrm{cb}$ & 74.31 & $0.97 \pm 0.14 \mathrm{Dbc}$ & 71.34 & 131.014 & 0.000 \\
\hline Profenofos & $\mathrm{cm} / \mathrm{L}$ & $7.37 \pm 0.44 \mathrm{Ab}$ & $3.07 \pm 0.20 \mathrm{BCd}$ & 55.24 & $1.70 \pm 0.23 \mathrm{Cc}$ & 73.88 & 1.17 & $\pm \quad 0.20 \mathrm{Cc}$ & 80.33 & $0.40 \pm 0.09 D C$ & 83.53 & 113.566 & 0.000 \\
\hline Control & 0 & $10.53 \pm 0.52 \mathrm{Aa}$ & $9.80 \pm 0.53 \mathrm{Ba}$ & & $9.30 \pm 0.40 \mathrm{BCa}$ & & 8.50 & $\pm \quad 0.40 \mathrm{Ca}$ & & $3.47 \pm 0.23 \mathrm{Da}$ & & 41.777 & 0.000 \\
\hline F value & - & 6.356 & 106.982 & & 177.878 & & & 134.219 & & 70.745 & & & \\
\hline$P$ value & . & 0.000 & 0.000 & & 0.000 & & & 0.000 & & 0.000 & & & \\
\hline
\end{tabular}

Means within a column followed by the same letter are no significantly different using Duncan's Multiple Range Test. Small letters indicate to the significant differences between days while capital letters indicate to significant differences between treatments. IS= insignificant 


\section{Effect of photosensitizer on Enzyme:}

Table 3. $\alpha$ - Esterase enzyme activities in the homogenates of susceptible strain $2^{\text {nd }}$ instar of $S$. littoralis after treatment with photosensitizer

\begin{tabular}{|c|c|c|c|c|c|c|c|c|c|c|c|c|}
\hline \multicolumn{13}{|c|}{$\alpha$ - Esterase activity ( $\mu g \alpha$ - naphtho/ min. / g.b.wt.) } \\
\hline \multirow[b]{2}{*}{1} & \multirow{2}{*}{$\begin{array}{l}\text { Compound } \\
\mathrm{Cu} \text { ih }\end{array}$} & \multicolumn{3}{|c|}{$2^{\text {nd }}$ Instar larvae } & \multirow{2}{*}{$\begin{array}{l}\% \\
38.37\end{array}$} & \multirow{2}{*}{$\frac{*}{-61.63}$} & \multirow{2}{*}{$\begin{array}{l}\text { Compound } \\
\mathrm{Mg} \mathrm{hh}\end{array}$} & \multicolumn{3}{|c|}{$2^{\text {nd }}$ Instar larvae } & \multirow{2}{*}{$\begin{array}{c}\% \\
18.16\end{array}$} & \multirow{2}{*}{$\frac{*}{-81.84}$} \\
\hline & & 831.67 & \pm & 0.81 & & & & 393.67 & \pm & 0.61 & & \\
\hline 2 & Cu $2 \mathrm{~h}$ & 492.67 & \pm & 0.63 & 22.73 & -77.27 & $\mathrm{Mg} 2 \mathrm{~h}$ & 595.00 & \pm & 0.80 & 27.45 & -72.55 \\
\hline 3 & Cu Dark & 477.00 & \pm & 0.62 & 22.01 & -77.99 & Mg Dark & 519.67 & \pm & 0.97 & 23.97 & -76.03 \\
\hline 4 & Control & 2167.67 & \pm & 0.58 & 100.00 & 00,00 & Control & 2167.67 & \pm & 0.58 & 100.00 & 00.00 \\
\hline
\end{tabular}

* = percentage decrease relative to control

Results in table (3) show a good correlation found between the results of bioassays and biochemical assays in our study. Photosensitizer; magnesium chlorophyllin and copper chlorophyllin affected $\alpha$ - Esterase in the $2^{\text {ndinstar larvae. }}$ Photosensitizer caused reduction in the activity of $\alpha$ - Esterase in all treated larvae relative to the controls of the $2^{\text {nd }}$ instars S.littoralis.

Table 4. $\beta$ - Esterase enzyme activities in the homogenates susceptible strains $2^{\text {nd }}$ instar of $S$. littoralis after treatment with photosensitizer

\begin{tabular}{|c|l|l|l|l|l|l|l|l|l|l|l|l|l|c|}
\hline \multicolumn{10}{|c|}{$\beta$ - Esterase activity $(\mu \mathrm{g} \beta$-naphtho/ min. / g.b.wt.) } \\
\hline & Compound & \multicolumn{1}{|c|}{ Instar larvae } & $\%$ & $*$ & Compound & $2^{\text {nd }}$ Instar larvae & $\%$ & $*$ \\
\hline 1 & $\mathrm{Cu} \mathrm{1h}$ & 349.7 & \pm & 0.97 & 242.34 & 142.34 & $\mathrm{Mg} 1 \mathrm{~h}$ & 232.3 & \pm & 0.97 & 160.98 & 60.98 \\
\hline 2 & $\mathrm{Cu} \mathrm{2h}$ & 341.3 & \pm & 0.61 & 236.52 & 136.52 & Mg $2 \mathrm{~h}$ & 167.7 & \pm & 0.73 & 116.22 & 16.22 \\
\hline 3 & $\mathrm{Cu}$ Dark & 223.7 & \pm & 0.82 & 155.02 & 55.02 & Mg Dark & 280.7 & \pm & 0.62 & 194.53 & 94.53 \\
\hline 4 & Control & 144.3 & \pm & 0.63 & 100.00 & 00.00 & Control & 144.3 & \pm & 0.63 & 100.00 & 00.00 \\
\hline
\end{tabular}

* = percentage increase relative to control

Results in table (4) show that $\beta$ - esterases had greater activity in all treated the $2^{\text {nd }}$ instar S.littoralis by copper chlorophyllin more than all treated $2^{\text {nd }}$ instar S.littoralis by magnesium chlorophyllin of relative to the controls of the $2^{\text {nd }}$ instars Spodoptera littoralis. A member of the esterase cluster may play a role in detoxification of xenobiotic esters (Gacar and Tasksn, 2009). Increased esterase activity is a major mechanism of resistance in many insect species (Zhou et al., 2002). The present study had shown that Acetylcholinesterase activity table (5) was inhibited after exposed of $2^{\text {nd }}$ instar to both copper chlorophyllin, magnesium chlorophyllin. Inhibition of Acetylcholinesterase has been used as biomarker for insecticides (Payne et al., 1996). 
Table 5. Acetylcholinesterase activities in the homogenates susceptible strains $2^{\text {nd }}$ instar of $S$. littoralis after treatment with photosensitizer

\begin{tabular}{|c|c|c|c|c|c|c|c|c|c|c|c|c|}
\hline \multirow[b]{3}{*}{1} & \multicolumn{12}{|c|}{ AchE activity ( $\mu \mathrm{g} \mathrm{AChBr} / \mathrm{min} / \mathrm{g}$ body weight ) } \\
\hline & Compound & $2^{\text {nd }}$ Instar la & vae & & $\%$ & $*$ & Compound & $2^{\text {nd }}$ Insta & larv & & $\%$ & * \\
\hline & $\mathrm{Cu} 1 \mathrm{~h}$ & 188.33 & \pm & 0.97 & 93.54 & -6.46 & $\mathrm{Mg} 1 \mathrm{~h}$ & 216.00 & \pm & 0.61 & 107.29 & 7.29 \\
\hline 2 & $\mathrm{Cu} 2 \mathrm{~h}$ & 207.67 & \pm & 0.63 & 103.15 & 3.15 & $\mathrm{Mg} 2 \mathrm{~h}$ & 182.00 & \pm & 0.62 & 90.40 & -9.60 \\
\hline 3 & $\mathrm{Cu}$ Dark & 190.67 & \pm & 0.73 & 94.71 & -5.29 & Mg Dark & 207.33 & \pm & 0.97 & 102.98 & 2.98 \\
\hline 4 & Control & 201.33 & \pm & 0.86 & 100.00 & 00.00 & Control & 201.33 & \pm & 0.86 & 100.00 & 00.00 \\
\hline
\end{tabular}

$*=$ increase or decrease percentage relative to control

\section{DISCUSSION}

The results showed that, efficiency of photosensitizers as pesticides is influenced by a variety of factors, concentration of photosensitizers and duration exposure light. The rate of the photosensitized killing of insects appeared to increase with prolongation of post treatment exposure to light (Ben Amor et al. 1998). $n$ these experiments, the intak of chlorophyllin under a rule of constant darkness lead to no serious mortality during the larval phase. Therefore, sunlight activated pesticides, based on photosensitizer compounds, which could be used as effective bio- insecticides; represent a viable to traditional chemical insecticides (Filiberti et al. 2009). Fetal photochemical reactions cause death of the target pest when ingested food, these compounds accumulate inside the pest; subsequently, exposure to visible light. Our results suggest that, Light, photosensitizer and oxygen is potentially damaging, Singlet oxygen one of the main responsible for caused harmful in biological systems (Weishaput et al., 1976).

\section{REFERENCES}

1. Abdel-Hafez, M. M; A. Mohanna; M. A. Afifi and A. H. Eid. 1993. Effect of IGR/insecticide mixtures on esterases activity of $S$. littoralis. J. Product and Dev. I (2):153- 164.

2. Ben Amor $\mathrm{T}$ and G. Jori. 2000. Sunlight-activated insecticides: historical background and mechanisms of phototoxic activity. Insect-Biochem \&Molecul.Biol. 30: 10, 915-925

3. Black, H. S. 1987. Potential involvement of free radical reaction in ultraviolet light-mediated cutaneous damage. Photochem \& Photobiol., 46, 213-221.

4. Brattsten, L.B. 1992. Potential role of plant allelochemicals in development of insecticide resistance. In: Molecular mechanism of insecricide resistance, diversity among insects. American Chemical Society Symposium Series. Mullin, C. A., \& Scott, J. G. [eds]. pp. 313-348, Washington DC.

5. El-Defrawi, M. E.; A. Toppozada; N. Mansour and M. Zeid. 1964. Toxicological studies on Egyptian cotton leaf worm Prodenia litura (F.). I: Susceptibility of different larval instars to insecticides. J. Econ. Entomol., 57 (4): 591-593. 
6. Filiberti A, Rabossi A, Argaraña CE, Quesada-Allué LA. 2009. Evaluation of Phloxine B as photoinsecticide on Immature Stages of the Horn Fly, Haematobia irritans (Diptera: Muscidae). Aust. J. of Entomol., 48:72-77.

7. Gacar, F. and Tasksn, V. 2009. Partial base sequence analysis of MdaE7 gene and ali-esterase enzyme activities in field collected populations of housefly (Musca domestica L.) from Mediterranean and Aegean Regions of Turkey. Pestic. Biochem. Physiol., 94: 86-92.

8. Heitz, J.R. 1987. Development of photoactivated compounds as pesticides. In light activated pesticides.(Edited by J.R. Heitz and K.R. Dowrum). American Chemical Society Symposium Series 339, Washington, DC, pp. 1-21.

9. Henderson, C.F. and E. Tilton. 1955. Tests with acaricides against the brown wheat mite. Journal of Econ. Entomol., 48: 157-161.

10. Herron, G.; Cottage, E.; Wilson, L. and Gunning, R. 2004. Insecticide resistance in cotton aphid (Aphisgossypi): results and management options after 2002/2003 and 2003/2004. In Crop Protection "Quality Cotton" - A Living Industry.12th Aust. Cotton Conf., 10-12th August.

11. Koul S, Dhar A, Bindroo BB. 1994. Industrial utilization of sericultural resources in China. Pop Sci 3: 29-34.

12. Majumder SK. 1997. Scope for new commercial products from sericulture. Indian Silk 35: 13-18.

13. Mcneill M.R. and Goldson S.L. 2001. responses of two leafroller species to the Photoactive dye phloxine b New Zealand Plant Protection 54 (2001): 27-32

14. Payne, J.F., Mathieu, A., Melvin, W., Fancey, L.L. 1996. Acetylcholinesterase, an old biomarker with new future? Field trials in association with two urban rivers and paper mill in Newfoundland. Mar. Pollut. Bull. 32, 225-231.

15. Pethuan, S., Jirakanjanakit, N.; Saengtharatip, S.; Chareonviriyaphap, T.; Kaewpa, D. and Rongnoparut, P. 2007. Biochemical studies of insecticide resistance in Aedes (Stegomyia) aegypti and Aedes (Stegomyia) albopictus (Diptera: Culicidae) in Thailand. Tropical Biomedicine, 24(1): 7-15.

16. Riskallah, M. R.; W. M. El-Deeb and M. A. El-Guindy. 1979. Esterase activity in relation to insecticides resistance in the Egyptian cotton leafworm. Zeitschrift fur Ange wandte Entomologie, 88 (1):70-76.

17. Simpson, D.R.; Bulland, D.L, and Linquist, D. A. 1964. A Semimicrotechnique for Estimation of Cholinesterase Activity in Boll Weevils. Ann. Ent. Soc. Amer., 57:367-371.

18. Spikes, I.D. 1985. The historical development of ideas on applications of photosensitized reactions in the health science, R.V. Benssason. E.J. Land, G.Jori 
and T.G. Truscott (eds.) pp. 124-144 In Primary photoprocesses in biology and medicine. Plenum Press New York.

19. Svaasand, L.O., Martinelli, E., Gomer, G.J., Profio, A.E. 1990. Optical characteristics of tumours in the visible and near-infrared. Proc. SPIE 1203, 2-21.

20. Van Asperen, K. 1962. A study of housefly esterase by means of sensitive colourimetric method. J. Insect Physiol., 8: 401-416.

21. Villani, F., White, G.B., Curtis, C.F. and Miles, S.J. 1983. Interitance and activity of some esterases associated with organophosphate resistance in mosquitoes of the complex of Culex pipiens L. (Diptera:Culicidae). Bull. Ent. Res. 73, 153-170.

22. Weishaupt, K.R., Gomer, C.J. and Dougherty, T.J. 1976. Identification of singlet oxygen as the cytotoxic agent in photoinactivation of a murine tumor. Cancer Research, 36, 2326-2329.

23. WHO - World Health Organization 1981. Instructions for determining the susceptibility or resistance of adult mosquitoes to organochlorine, organophosphate and carbamate insecticides - Diagnostic test. Document WHO/VBC/81.806. WHO, Geneva, 7 pp.

24. WHO - World Health Organization 1998. Test procedures for insecticide resistance monitoring in malaria vectors, bio-efficacy and persistence of insecticides on treated surfaces (WHO/CDS/CPC/MAL/98.12), WHO, Geneva, 46 pp.

25. Zhou, X.; Scharf, M.E.; Parimi, S.; Meinke, L.J.; Wright, R.J.; Chandler, L.D. and Siegfried, B.D. 2002. Diagnostic assays based on esterase mediated resistance mechanisms in western corn rootworms ( Coleoptera: Chrysomelidae). J. Econo. Entomol., 95: 1261-266. 


\title{
تقييم سمية مركبات الكلوروفيلين على السلالة الحقلية و

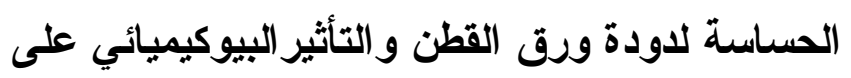 نشاط ( الفا-بيتا) استيريزو الاستيل كولين استريز
}

\author{
سامح مصطفى عبدالنبى \\ معظ بحوث وقاية النباتات - مــركز البحوث الزراعية - الدقى - جيزة - مصر
}

كلوروفيلين ، ملح الصوديوم و النحاس ويذوب في الماء ، الكلوروفيل صبغه خضر اء ولديها

العديد من الخصائص المفيدة. أجريت التجارب الحقلية فى محطة كلية الزر اعة ، جامعة القاهرة ،

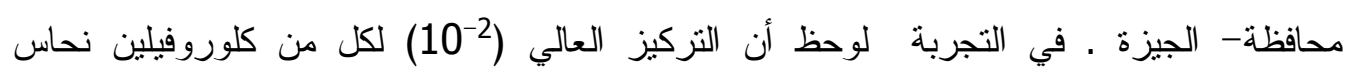
الصوديوم و كلوروفيللين النحاس المغنيسيوم أكثر فعالية من التركيز (3-10) فى المعاملات الحقلية و السلالة الحساسة ، وتم تحديد مستوى نشاط إنزيمات الفا استريز ، بيتا استريزو استيل كولينفي

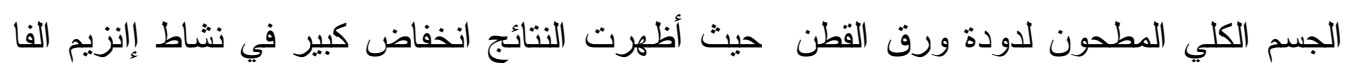
استريز ، بينما بيتا استريز أظهرت زيادة في النشاط ، و أظهرت النتائج في معظم المعاملات لانزيم أسنيل كولين نشاط منخفض. 